\title{
THE EFFECT OF ALPHA-MANGOSTIN IN BALANCING THE RATIO OF CYTOKINES PRO-AND ANTI-INFLAMMATION-GAMMA (IFN- $\gamma /$ IL-10) AND SEVERITY OF THE DISEASE IN MICE INFECTED WITH MYCOBACTERIUM TUBERCULOSIS MULTIDRUG-RESISTANT
}

\author{
DYAN KUNTHI NUGRAHAENI ${ }^{1,2 *}$, SUHARYO HADISAPUTRO ${ }^{1}$, ARI SUWOND0 ${ }^{1}$, EDI DHARMANA ${ }^{1}$ \\ ${ }^{1}$ Doktoral Program of Medical and Health Science, Faculty of Medicine, Diponegoro University, Semarang, Central Java, Indonesia. ${ }^{2}$ Public \\ Health Study Program, School of Health Sciences Jenderal Achmad Yani, West Java, Indonesia. Email: dyankunthi@yahoo.co.id
}

Received: 08 August 2016, Revised and Accepted: 13 September 2016

\section{ABSTRACT}

Objective: The objective of this study was observed to measure the effect of alpha-mangostin in balancing the ratio of interferon-gamma (IFN- $\gamma$ ) and interleukin-10 (IL-10), and the severity of the disease in mice which infected with Mycobacterium tuberculosis multidrug-resistant (TB-MDR).

Method: Infected BALB/c mice were consisted of five groups: Treated with anti-TB drugs $+\alpha$-mangostin, treated with anti-TB drugs, given $\alpha$-mangostin during treatment, and control group. Cytokine levels of culture supernatant of spleen cells were measured by enzyme-linked immunosorbent assay. The number of bacterial colonies was derived from a primary cell culture of bronchoalveolar lavage. Statistical analysis was performed with Anova, Kruskal-Wallis test and correlation Pearson, and Spearman-rank test.

Result: Median IFN- $\gamma$ production was higher in mice, which given with $\alpha$-mangostin during treatment is $1838.2 \mathrm{pg} / \mathrm{ml}$ and control is $1585.5 \mathrm{pg} / \mathrm{ml}$ compared treated with anti-TB drugs $+\alpha$-mangostin $(1312 \mathrm{pg} / \mathrm{ml})$ and anti-TB drugs $(1429.3 \mathrm{pg} / \mathrm{ml})(\mathrm{p}>0.05)$. The highest result production of median IL-10 in the $3^{\text {th }}$ group is $(465.91 \mathrm{pg} / \mathrm{ml})$ and the lowest in the control group is $195.29 \mathrm{pg} / \mathrm{ml}, \mathrm{p}>0.05$. Median IFN- $\gamma / \mathrm{IL}-10$ ratio of the $3^{\text {th }}$ group very low (3.94), it means the $3^{\text {th }}$ group is experienced with severity of TB. Alpha-mangostin was decreased in severity of disease based on the number of TB-MDR bacterial colonies $(\mathrm{p} \leq 0.05)$.

Conclusion: $\alpha$-mangostin have an effect on the balancing IFN- $\gamma / \mathrm{IL}-10$ ratio and reduce a severity of TB-MDR with using immunomodulator.

Keywords: Tuberculosis multidrug-resistant, Alpha-mangostin, Interferon- $\gamma /$ interleukin-10 ratio, Number of tuberculosis multidrug-resistant bacterial colonies.

(C) 2016 The Authors. Published by Innovare Academic Sciences Pvt Ltd. This is an open access article under the CC BY license (http://creativecommons. org/licenses/by/4. 0/) DOI: http://dx.doi.org/10.22159/ajpcr.2016.v9s3.14544

\section{INTRODUCTION}

Tuberculosis (TB) is a deadly human disease brought by TB, approximately 9.6 million people suffer from TB and 1.5 million died from the disease in 2014 [1]. The three countries that a distinguished as the largest number of incidence cases in 2014 were India (2.2 million); Indonesia (1 million), with prevalence rate: 647/100.000 [2]; China (0.93 million). The strategy of prevention and eradication of ТВ constrained due to drug-resistant $\mathrm{TB}$, in particularly TB multidrugresistant (TB-MDR). In 2013s, an estimated 210,000 people died from TB-MDR, and there were approximately 480.000 new cases of TB-MDR worldwide [1].

Individuals are infected with $\mathrm{TB}$, only $5-10 \%$ developed with TB active as a consequence defect of T-cells and macrophages function or the ability of phagocytosis [3]. The activity of T-cells (lymphocytes T) was sensitized, and macrophage activation is key to host immunity against intracellular infections such as pulmonary TB [4]. Protection against M. TB infection is a function of the interaction between host T-cells and macrophages and that is coordinated by cytokines [5]. Macrophages represent the first line of defense against invading bacterial pathogens such as Mycobacterial TB (MTB) [6].

Stimulation of antigen MTB will response T-cells, T-cell CD4+ play a major role to against microbial infection by secreting pro-inflammatory cytokines such as interferon-gamma (IFN- $\gamma$ ). T-cells in the sensitized individuals produce IFN- $\gamma$ when they exposure the antigens of MTB [7]. IFN- $\gamma$ produced by the activation of $\mathrm{CD}^{+}{ }^{+} \mathrm{T}$-cells, $\mathrm{CD}^{+} \mathrm{T}$-cells, and NK cells (Natural Killer cells). The principal effectors of innate immunity against intracellular bacteria are phagocytes and NK cells. NK cells were produced IFN- $\gamma$ as a triggers the activation of macrophages and increasing destruction of intracellular bacteria such as MTB [4]. Cytokine IFN- $\gamma$ stimulated and activated macrophages to produce a substance that eliminates bacteria, including oxidase enzyme in phagocytes, such as reactive oxygen intermediates (ROI), enzyme inducible nitric oxide synthase, and enzyme lysozyme [4-8].

Recognition of MTB by phagocytic cells results in cell activation and production of cytokines, which in itself induced further activation and cytokine production in a complex process up regulation and down regulation. Several cytokine plays a key role in proinflammatory mechanism and the outcome of mycobacterial infections [3]. IFN- $\gamma$ production in response to MTB was lowered in patients with TB, particularly in those with far advanced disease [9]. The T-cell response develops especially $\mathrm{T}$-cell $\mathrm{CD} 4^{+}$may contribute to differences in susceptibility to the disease or outcome [3]. As well as in uncontrolled infection of $\mathrm{TB}$, the activated macrophages by stimulating IFN- $\gamma$ caused tissue damage, therefore required inhibition cytokine such as IL-10 [10]. Interleukin-10 (IL-10) inhibits the protective immune response to pathogens by blocking the production of pro-inflammatory cytokines, such as IFN- $\gamma$, by direct action antigen-presenting cells (APCs) such as macrophages [11]. Meta-analysis recently published reinforces the critical importance of IFN $-\gamma$ as a genetic marker for TB resistant, while IL-10 indeed had some specific effect on TB the disease and severity but does not affect the susceptibility [12].

IL-10 produced by Th2 cells and a subset of T-cells including cells Th 17, $\mathrm{B}$ cells, neutrophils, macrophages, dendritic cells, and T regulatory cells (Tregs) [11]. Tregs are a subpopulation of CD4 $4^{+} \mathrm{T}$-cells, expressing and secreting IL-10 and TGF- $\beta$, cytokine IL-10 as a barrier and decreasing Th 1 cell response in patients with TB infection. Tregs cells are a major source of cytokines IL-10, which serves to suppressed the function of 
APC and macrophages activation [4,5]. Infections TB were performed in mice showed that macrophages with excessive production of IL-10 causes of decreased production of ROI and RNI and reduced the function macrophages [11].

Severity and pathological damage because of the infection depend on the balancing between pro-inflammatory and anti-inflammatory cytokines (IFN- $\gamma /$ IL-10), which is related to the ability to control granulomatous or control bacterial burden or the number of bacteria in granuloma. Infection of mice with MTB can be increased fatality rate. It caused a higher number of bacterial TB or highly bacterial burden in mice [13]. Pro- and anti-inflammation cytokines play a key role in protection and pathogenesis of mycobacterial infection, and their balance and dynamic changes may control or predict clinical outcome. Balancing cytokines between Th1 and Th2 subset (IFN- $\gamma / \mathrm{IL}-10$ ratio) may influence disease outcome and significantly correlated with TB cure [14]. Balancing between differences types of cytokine, especially IFN- $\gamma /$ IL-10 ratio was associated with more killing of numerous MTB in granuloma $[14,15]$.

It is now generally accepted that new drugs to cure TB are urgently needed due to the recent increment of TB-MDR. The development of new drugs to cure TB is urgently needed based on the structure and modification of drugs derived from herbal products [17]. The xanthones, $\alpha$ - and $\gamma$-mangostin, are major bioactive compounds found in fruit hulls of the mangostin [18]. $\alpha$-mangostin has some pharmacological activities such as antioxidant [19], anti-TB [16,19], MTB-MDR [19,20] anti-inflammatory activities [21], pro-inflammatory activities [18], and increased the permeability of the bacterial cell membrane [22-24]. The compound $\alpha$-mangostin is expected to contribute to the fight against and eliminate TB infection and MTB-MDR $[16,19]$. The purpose of this research is to know the effect of $\alpha$-mangostin in balancing the ratio of cytokines pro-inflammation (IFN- $\gamma$ ) and anti-inflammation (IL-10) and severity of disease in mice which infected with MTB-MDR.

\section{METHODS}

\section{Animals}

Male BALB/c mice (6-8 weeks old) were obtained from an animal laboratory at the Health of Medicine Study Program, School of Health Science Jenderal Achmad Yani Cimahi and Drug-Screening Laboratory at faculty of medicine Diponegoro University. Mice were housed in environmentally controlled animal facilities and the animal room maintained at $25^{\circ} \mathrm{C}$ with a $12 \mathrm{hrs}$ light or dark cycle; mice were acclimated for at least 1 week. All experiments were approved by Health Research Ethics Committee Faculty of Medicine, University Diponegoro and General Hospital Dr. Kariadi Semarang, Central Java with the number of Ethical Clearance 573/EC/FK-RSDK/2015.

\section{Bacteria and infection}

Isolate of TB-MDR strains from patients with active TB at the Health Laboratory of West Java Province. Four groups of mice (each contains from 5 mice) were infected by $0.1 \mathrm{ml}$ of bacterial suspension per mice (dose of $10^{5}$ to $10^{6}$ viable colony forming unit or CFU) through tail vein injection. The group of infected mice was observed for 28 days and the dead time for each group was recorded. Compound of $\alpha$-mangostin obtained from Aktin Chemical, Inc. Hi-Tech Zone, Yongfeng Plaza, No 52 Yongfeng Road Chengdu China.

\section{Experimental design}

The design of this study is using a posttest with the only control group design. 20 mice were randomized and divided into 4 groups, Group I: Fourteen (14) day after infection treated with $\alpha$-mangostin with human-equivalent doses of $6.95 \mathrm{mg} / \mathrm{kg}$ body weight and anti-TB drugs (once a day given per oral); Group II: Treated with anti-TB drugs given. In Group III was given $\alpha$-mangostin during treatment (early stage given $\alpha$-mangostin in 1-7 days, then infected with TB-MDR at 7-21 day and given anti-TB drugs at 21-28 day observation). The control group was infected TB-MDR without treatment (positive control).

\section{Cytokine measurement}

After 28 days of treatment, mice were sacrificed used by cervical dislocation. Spleens from twenty mice (each contains 5 mice) were removed rapidly after sacrifice and a sterile autopsy were performed. The organs were transferred into $2 \mathrm{~mm}$ diameter glass beads each containing $1 \mathrm{ml}$ FBS (fetal bovine serum). Spleen lymphocytes were extracted, and $3 \times 10^{7} / \mathrm{ml}$ lymphocytes were cultured in 24-well plates in the RPMI- 1640 cell culture medium containing $10 \%$ FBS and $100 \mathrm{U} / \mathrm{ml}$ penicillin, $100 \mu \mathrm{g} / \mathrm{ml}$ streptomycin and stimulated with HPA. Supernatants were collected after 48 and 72 hours and then plates incubated in $5 \% \mathrm{CO} 2$ at $37^{\circ} \mathrm{C}$. IFN- $\gamma$ and IL-10 production were measured by enzyme-linked immunosorbent assay using Mouse IFN gamma Quantikine Cat. No. MIF00 and Mouse IL-10 Quantikine Cat. No. M10000B, following the manufacturer protocol. Standard curves for each cytokine were generated using reference cytokine concentration supplied by the manufacturer.

\section{Bronchoalveolar lavage (BAL) and histology of the lung}

BAL has been widely used for clinical research because BAL fluid contains both biochemical and cytological indicators of cellular responses to infection include TB infection [25]. Bronchoalveolar lavage used to know of a number of colonies multidrug-resistant MTB. The abdominal cavity was opened, exsanguination was performed via the aorta abdominalis, and the chest cavity was dissected to expose the lung and the trachea. One (1) $\mathrm{ml}$ syringe connected 27 gauges and then gently inserted into the trachea and $0.9 \mathrm{ml}$ chilled saline was administered and aspirated slowly through the needle hub. The liquid of bronchoalveolar lavage (BAL) accommodated with micro tube $1 \mathrm{ml}$. Bronchoalveolar lavage stored at $2-8^{\circ} \mathrm{C}$ before culture and incubation. Bronchoalveolar lavage cultured and incubation on Lewenstein Jensen medium at $35-37^{\circ} \mathrm{C}$ and observed for 8 weeks. The present bacterial TB in mice with infected MTB-MDR is confirmed from the histology of the lung tissue and staining with Ziehl-Neelsen method to find acid-fast bacilli.

\section{Statistical analysis}

Results are reported in the mean \pm standard deviation (SD), median, minimum, and maximum value. To compare the differences mean of cytokines (IFN- $\gamma$ and IL-10) between four groups were calculated using Anova (statistical parametric), while differences mean number of bacterial colonies used Kruskal-Wallis test (statistically nonparametric). The correlation cytokines IFN- $\gamma$ and IL-10 with IFN- $\gamma /$ IL-10 ratio were assessed using correlation pearson (statistical parametric), and the correlation between IFN- $\gamma /$ IL-10 and the number of bacterial colonies used Spearman-rank test (statistical nonparametric). Correlation coefficients were calculated and identified as very weak (0-0.19), weak (0.20-0.39), moderate $(0.40-0.59)$, strong $(0.60-0.79)$, or very strong $(0.80-1.0)$. All statistical analyses were one sided, and $\mathrm{p} \leq 0.05$ was considered as statistically significant.

\section{RESULTS}

The median of pro-inflammatory cytokine (IFN- $\gamma$ ) was strongly increased to response TB infection in the $3^{\text {rd }}$ group that was given $\alpha$-mangostin during treatment $(1838.2 \mathrm{pg} / \mathrm{ml})$ and lowest in the group treated with anti-TB drugs and $\alpha$-mangostin $(1312 \mathrm{pg} / \mathrm{ml})$. The results of data analysis showed that administration of alpha-mangostin in the Groups 1-3 and control groups did not significantly increased IFN- $\gamma$ production $(\mathrm{p}>0.05)$ (Table 1$)$. Median IL-10 production was strongly depressed to response TB infection in the control group (195.29 $\mathrm{pg} / \mathrm{ml})$, and the highest in the group was given $\alpha$-mangostin during treatment $(465.91 \mathrm{pg} / \mathrm{ml})$. Maximal value IL-10 in the group was given $\alpha$-mangostin during treatment $(1090.7 \mathrm{pg} / \mathrm{ml})$. The data analysis has shown that the production capacity of IL-10 in the treatment Group 1-3 and control groups did not statistically significant $(\mathrm{p}>0.05)$ (Table 1).

The median IFN- $\gamma / \mathrm{IL}-10$ ratio is the lowest in the group treated with anti-TB drugs and $\alpha$-mangostin and it was 3.94 , this due to higher 
production of cytokine pro-inflammation (IFN- $\gamma$ ) followed by higher production of cytokine anti-inflammation (IL-10). The lowest value IFN- $\gamma /$ IL-10 ratio in the group was given $\alpha$-mangostin during the treatment $(0.80)$, it means in the $3^{\text {rd }}$ group showed the severity of TB infection, it was indicated with the highest number of bacterial colonies TB-MDR. Alpha-mangostin did not significant to compare mean IFN- $\gamma /$ IL-10 ratio in treatment Group 1-3 ( $>0.05$ ). The result completely is shown in Table 1.

The number of colonies MTB-MDR from culture bronchoalveolar lavage, the higher count of bacterial colonies in the $3^{\text {rd }}$ group, it was given $\alpha$-mangostin during treatment. The number of colonies in the $3^{\text {rd }}$ group: 11 colonies, large colonies, color colonies of bacteria: Buff and dry, (shown in Fig. 1a). Result histology of the lung tissue in mice infected with TB-MDR found acid-fast bacilli (Fig. 1b). In the control group, maximal count of bacteria is 5 colonies MTB-MDR. While group treated with anti-TB drugs and $\alpha$-mangostin and the group treated with anti-TB drugs ( $1^{\text {st }}$ and $2^{\text {nd }}$ group) bacterial colonies were zero $(0)$, it's mean administration $\alpha$-mangostin can be used to eliminated and killing TB-MDR. In this research, administration alpha-mangostin after an incubation period of TB infection (14 $4^{\text {th }}$ day after infection) significant to decreased number of bacterial colonies MTB-MDR $(\mathrm{p} \leq 0.05)$ (Table 1$)$.

The results reveal a positive correlation between the production of cytokine IFN- $\gamma$ was correlated with IFN- $\gamma / \mathrm{IL}-10$ ratio $(\mathrm{r}=0.39 ; \mathrm{p} \leq 0.05)$, it was positive correlation that means the higher production of cytokine

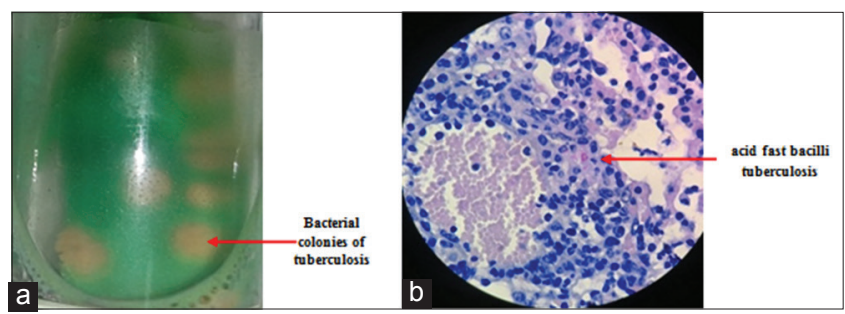

Fig. 1: The number of bacterial colonies of tuberculosis multidrug-resistant, (a) $3^{\text {rd }}$ group: 11 bacterial colonies

tuberculosis multidrug-resistant, large colonies, color: Buff and dry, (b) Acid fast bacilli from the histology of lung
IFN- $\gamma$ increased of IFN- $\gamma /$ IL-10 ratio (Fig. 2). The coefficient correlation between cytokine IFN- $\gamma$ and IFN- $\gamma / \mathrm{IL}-10$ ratio categorized weak. IFN- $\gamma$ production capacity contributed $12.9 \%$ to increase the ratio of IFN- $\gamma$ / IL-10 $\left(R^{2}=0.129\right)$

The correlation between production capacity of IL-10 and IFN- $\gamma /$ IL-10 ratio was negative correlation ( $r=-0.57 ; \mathrm{p} \leq 0.01)$, it means that the higher of production IL-10 can caused to decreased of IFN- $\gamma / \mathrm{IL}-10$ ratio (Fig. 2). The coefficient correlation between of IL-10 and IFN- $\gamma /$ IL-10 ratio was moderate correlation. IFN- $\gamma$ production capacity contributed to $32.5 \%$ to increase the ratio of IFN- $\gamma / \mathrm{IL}-10\left(\mathrm{R}^{2}=0.325\right)$.

The correlation between IFN- $\gamma / \mathrm{IL}-10$ ratio and the number of bacterial colonies TB-MDR was a negative correlation $(r=-0.398 ; p \leq 0.05)$, it means that the lower of IFN- $\gamma / \mathrm{IL}-10$ ratio can cause to increase of the number of bacterial colonies TB-MDR (Fig. 3). The coefficient correlation between IFN- $\gamma / \mathrm{IL}-10$ ratio was categorized weak. The ratio of IFN- $\gamma /$ IL-10 contributed to $7.9 \%$ to increase the number of bacterial colonies TB-MDR $\left(\mathrm{R}^{2}=0.079\right)$.

\section{DISCUSSION}

After inhalation with cMTB in the lungs, the first cells to be exposed to the microbial include alveolar macrophages and dendritic cells (DCS) of the lung, both of which readily phagocytosis MTB and become activated, producing the cytokines TNF- $\gamma$, IFN- $\gamma$ and IL-12 to promote host antimicrobial mechanisms [11], and initiating the activation of T helper (Th) cells [26]. In mycobacterial infection, Th1 type cytokines especially pro-inflammatory cytokines such as the capacity production of IFN- $\gamma$ plays an important role in protective immunity and the establishment of innate immunity against MTB [27]. While Th2 type cytokines or anti-inflammatory cytokine especially IL-10 inhibited production of IFN $-\gamma[3]$.

The clinical manifestations of infection with MTB and severity of disease in TB infection indicated they changed in balancing of cytokines that play a part in the MTB infection. The balancing of pro-inflammatory cytokines and anti-inflammatory is a very significant sign related to the progression of TB infection [5,28]. IFN- $\gamma$ may be one of the keys cytokine in the activation of macrophages for elimination and killing MTB. IL-10 of particular importance in reducing collateral tissue damage due to

Table 1: Mean \pm SD, median, minimal and maximal value of cytokines IFN- $\gamma(\mathrm{pg} / \mathrm{ml}), \mathrm{IL}-10(\mathrm{pg} / \mathrm{ml}), \mathrm{IFN}-\gamma / \mathrm{IL}-10$ ratio and number of bacterial colonies TB-MDR

\begin{tabular}{|c|c|c|c|c|}
\hline Mice groups $(n=5)$ & IFN- $\gamma(\mathrm{pg} / \mathrm{ml})$ & IL-10 (pg/ml) & IFN- $\gamma /$ IL-10 ratio & $\begin{array}{l}\text { Number of bacterial } \\
\text { colonies TB-MDR }\end{array}$ \\
\hline \multicolumn{5}{|l|}{ I } \\
\hline Mean & $1365.94 \pm 878.42^{*}$ & $230.37 \pm 67.29^{*}$ & $7.23 \pm 6.61^{*}$ & 0 \\
\hline Median & 1312.0 & 255.58 & 6.62 & 0 \\
\hline Minimal & 383.05 & 128.15 & 1.35 & 0 \\
\hline Maximal & 2312.6 & 285.73 & 18.05 & 0 \\
\hline \multicolumn{5}{|l|}{ II } \\
\hline Median & 1429.3 & 207.62 & 5.77 & 0 \\
\hline Minimal & 1063.1 & 81.56 & 2.42 & 0 \\
\hline Maximal & 2392.9 & 439.88 & 17.52 & 0 \\
\hline \multicolumn{5}{|l|}{ III } \\
\hline Mean & $1591.29 \pm 802.16^{*}$ & $450.75 \pm 409.75^{*}$ & $10.65 \pm 13.33^{*}$ & $2.8 \pm 4.6^{*}$ \\
\hline Median & 1838.2 & 465.91 & 3.94 & 0 \\
\hline Minimal & 404.89 & 36.35 & 0.80 & 1 \\
\hline Maximal & 2417.2 & 1090.7 & 32.78 & 11 \\
\hline Mean & $1488.56 \pm 741.88^{*}$ & $176.66 \pm 51.35^{*}$ & $10.13 \pm 8.29 *$ & $1.0 \pm 2.236^{* *}$ \\
\hline Median & 1585.5 & 195.29 & 8.11 & 1 \\
\hline Minimal & 355.11 & 90.47 & 1.69 & 0 \\
\hline Maximal & 2167.6 & 217.22 & 23.96 & 5 \\
\hline
\end{tabular}

*Data given in mean \pm SD $(n=20),{ }^{* * S t a t i s t i c a l l y ~ s i g n i f i c a n t ~ c o m p a r e d ~ t o ~ t h e ~ g r o u p ~ I ~ w i t h ~} \mathrm{p} \leq 0.05$ (LSD post hoc test), SD: Standard deviation, TB-MDR: Tuberculosis multidrug-resistant, IFN: Interferon, IL: Interleukin 
Table 2: Correlation cytokine IFN- $\gamma(\mathrm{pg} / \mathrm{ml})$ and IL-10 $(\mathrm{pg} / \mathrm{ml})$ with IFN- $\gamma / \mathrm{IL}-10$ ratio and number of bacterial colonies TB-MDR

\begin{tabular}{lll}
\hline Variable & Correlation $(\mathbf{r})$ & $\begin{array}{l}\text { Coefficient of } \\
\text { determination } \\
\mathbf{( R}^{2} \mathbf{)}\end{array}$ \\
\hline IFN- $\gamma$ with IFN- $\gamma /$ IL-10 ratio & 0.39 & 0.129 \\
IL-10 with IFN- $\gamma /$ IL-10 ratio & $-0.57^{* * *}$ & 0.325 \\
IFN- $\gamma /$ IL-10 ratio with number & $-0.398^{* *}$ & 0.079 \\
of bacterial colonies TB-MDR & & \\
\hline
\end{tabular}

${ }^{* *}$ statistically significant $(\mathrm{p} \leq 0.05),{ }^{* * *}$ statistically significant $(\mathrm{p} \leq 0.01)$,

TB-MDR: Tuberculosis multidrug-resistant, INF: Interferon, IL: Interleukin

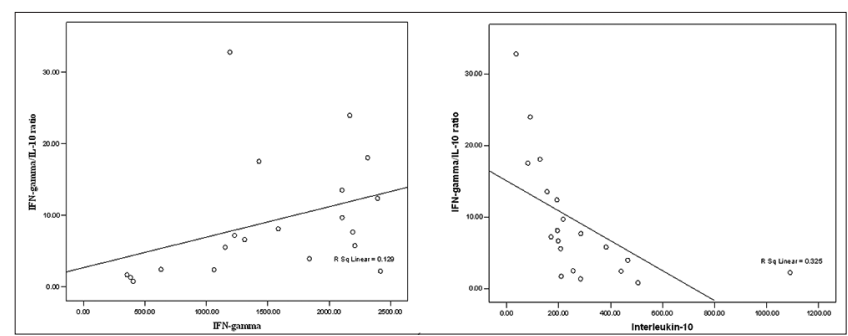

Fig. 2: Corelation of cytokines interferon-gamma/interleukin-10 with interferon-gamma/interleukin-10 ratio

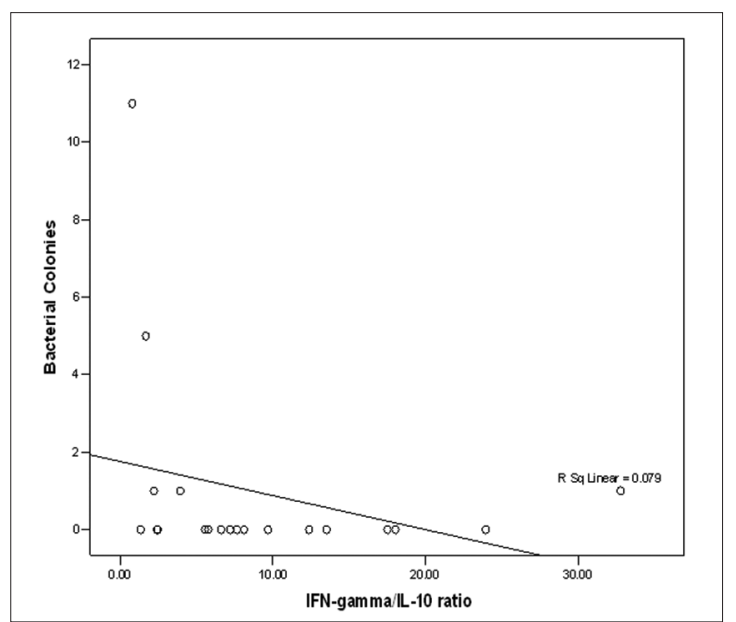

Fig. 3: Corelation of interferon-gamma/interleukin-10 ratio and number of bacterial colonies of Mycobacterium tuberculosis multidrug-resistant

the activating IFN- $\gamma$, particularly in the lung by dampening macrophage activation and by indirectly antagonizing IFN- $\gamma$ function [5].

Experiments in mice revealed that IFN- $\gamma$ is an important cytokine for macrophage activation and mycobacteria death in the intracellular environment [27]. Production IFN- $\gamma$ in response to M. TB were lowered in mice infected with $\mathrm{TB}$, particularly in those with far advanced disease [10]. The depression of IFN- $\gamma$ production contributing to defective host control of MTB infection in active TB [14]. Confirming prior studies showing that IFN- $\gamma$ production varies inversely with the severity of disease due to MTB [10]. IFN- $\gamma$ production a higher proportion of latent infection TB compares with TB active and uninfected healthy individual [29]. A high amount of IFN- $\gamma$ production is then assumed to be correlated with TB infection [7]. In this research shown that IFN- $\gamma$ production is more higher in the $3^{\text {rd }}$ group, that was given $\alpha$-mangostin during treatment and control group compare with the $1^{\text {st }}$ group treated with anti-TB drugs and $\alpha$-mangostin, its mean in the $1^{\text {st }}$ group health status and immunity in $1^{\text {st }}$ group increased and lead to the cure of multidrug-resistant MTB infection.
Anti-inflammatory cytokine (IL-10) managed a delicate balance between suppressing and activating host responses to microbial infection [11]. Increased IL-10 production in TB infection may hinder and inhibitor T-cell responses [5]. The highest result of IL-10 production may over control otherwise protective T-cell responses, causes high microbial load, which can lead to chronic infection, while small amount or depression of IL-10 production can be caused fatal host-mediated pathology. In this research, the $3^{\text {th }}$ group becomes over control of IL10 production and IL-10 depressed production in the control group that indicated progression and severity of TB infection in mice. This research in line with research Anshari et al. (2009) declared that IL-10 have a specific effect on TB infection, role of determining for severity of disease, but not susceptibility.

In this research reported that the ratio of cytokines (IFN- $\gamma / \mathrm{IL}-10)$ shows significant correlation with clinical severity in mice with infected TB-MDR based on number of bacterial colonies TB-MDR, lowest IFN- $\gamma / \mathrm{IL}-10$ ratio relating to severe disease, particularly in the $3^{\text {rd }}$ group. In the $3^{\text {rd }}$ group, MTB grow in culture with the number of bacterial colonies were 11 colonies, large colonies, color colonies are buff and dry. While the control group was growing 5 colonies of TB-MDR bacteria. Administration of $\alpha$-mangostin had an effect on the number of bacterial colonies in mice infected with MTB-MDR compared between the control group and the group was given $\alpha$-mangostin during treatment.

IFN- $\gamma /$ IL-10 ratio was considered to be particularly regulated biomarker signatures that correlated strongly with TB cure [14]. The IFN- $\gamma /$ IL-4 ratio was increased in most patients during therapy but was decreased in contacts that become ill, suggesting that this state is a direct consequence of the disease [30]. The IFN- $\gamma /$ IL-10 ratio increased in mice with $\alpha$-mangostin therapy and it means that the administration $\alpha$-mangostin associated with a cure of pulmonary TB. And while in the $3^{\text {rd }}$ group ( $\alpha$-mangostin during treatment), IFN- $\gamma /$ IL-10 ratio lowest and depressed, it means that the treatment alpha-mangostin during the experiment (before infection, bacterial infection phase, the incubation period and after infection) are related to the severity of TB infection.

Natural products are a proven for the development of novel scaffolds of drugs such as $\alpha$-mangostin, the active compound from Garcinia mangostana, they are received considerable as potential antimicrobial agents and decreased resistance of antibiotics [20,31]. Due to emergence of resistance to antibiotics especially MTB, the investigation and development of the new anti-TB drugs became a major focus of reseachers [31]. The compound of $\alpha$-mangostin served to increased the adaptive immune response to TB infection, of which can increased the number of $\mathrm{CD}^{+}{ }^{+} \mathrm{T}$-cells or $\mathrm{CD}^{+}{ }^{+} \mathrm{T}$-cells [19], by increasing the number of T-cells, so as to achieve an amount sufficient to stop the growth of TB bacteria [32]. Therefore the compound of $\alpha$-mangostin significantly increased the immune response and health status [19]. Alpha-mangostin can be used as adjuvant treatment of multidrugresistant MTB infection. That can be used to reduce the progression and severity of TB infection. Period administration of $\alpha$-mangostin must be considered and should be given in the period between 2-3 weeks postinfection, particularly on $14^{\text {th }}$ day after infected, which is in the period of T-cells become activated and differentiated to be an effector cells and begin to proliferated in tubercles and then activating the macrophages to eliminated and killing MTB [32].

\section{CONCLUSION}

Alpha-mangostin have an effect on the balancing cytokines of proinflammatory and anti-inflammatory (IFN- $\gamma /$ IL-10 ratio), it can be eliminated and killing mycobacterial, therefore can decrease the severity of TB infection. Alpha-mangostin can be used as immunomodulatory or adjuvant treatment against MTB-MDR.

\section{ACKNOWLEDGMENTS}

This research was funded in part by desentralisasi 2015 grants from the Indonesian Ministry of Research and Technology. Scholarships from 
BPP-DN, Indonesia Ministry of Research and Technology. We thank to Dr. Muchlis AUS., SpPD-KPTI, Prof. Dr. dr. Hertanto WS., MS. Sp.GK, Dr. dr Sri Andarini I., M.Kes, Professor Dr. dr. Hendro W., M.Sc. Tropmed, DMM, Sp.MK and Rasipin dr, M.Kes to their contribution of this research.

\section{REFERENCES}

1. WHO. Global Tuberculosis Report 2013. Geneva: World Health Organization; 2013.

2. WHO. Tuberculosis Profile. Geneva: World Health Organization; 2014

3. van Crevel R, Ottenhoff TH, van der Meer JW. Innate immunity to Mycobacterium tuberculosis. Clin Microbiol Rev 2002;15(2):294-309.

4. Baratawidjaja K, Rengganis I. Imunologi Dasar. $12^{\text {th }}$ ed. Jakarta: Balai Penerbit Fakultas Kedokteran Universitas Indonesia; 2014.

5. Masood KI, Rottenberg ME, Salahuddin N, Irfan M, Rao N, Carow B, et al. Expression of M. Tuberculosis-induced suppressor of cytokine signaling (SOCS) 1, SOCS3, FoxP3 and secretion of IL-6 associates with differing clinical severity of tuberculosis. BMC Infect Dis 2013;13:13.

6. Weiss G, Schaible UE. Macrophage defense mechanisms against intracellular bacteria. Immunol Rev 2015;264(1):182-203.

7. Preeti S, Pradeep K, Rachna S, Kumar AV. Futuristic scope of biomarkers in tuberculosis. Asian J Pharm Clin Res 2015;8(4):248-50.

8. Murphy K. Janeway's Immuno Biology. $8^{\text {th }}$ ed. New York, USA Garland Sciences, Tailor \& Francis Group, LLC and Informa Bussines; 2011

9. Kuo HP, Wang CH, Huang KS, Lin HC, Yu CT, Liu CY, et al. Nitric oxide modulates interleukin-1beta and tumor necrosis factor-alpha synthesis by alveolar macrophages in pulmonary tuberculosis. Am J Respir Crit Care Med 2000;161(1):199-2.

10. Shams H, Wizel B, Weis SE, Samten B. Contribution of CD8(+) T cells to gamma interferon production in human tuberculosis. Infect Immun 2001;69(5):3497-501.

11. Redford P, Murray P, Garra A. The role of IL-10 in immune regulation during $M$. tuberculosis infection. Mucosal Immunol 2011;4(3):261-70.

12. Ansari A, Talat N, Jamil B, Hasan Z, Razzaki T, Dawood G, et al. Cytokine gene polymorphisms across tuberculosis clinical spectrum in Pakistani patients. PLoS One 2009;4(3):e4778.

13. Ufimtseva E. Mycobacterium-host cell relationships in granulomatous lesions in a mouse model of latent tuberculous infection. Biomed Res Int 2015;2015:948131.

14. Sahiratmadja E, Alisjahbana B, De Boer T, Adnan I, Maya A, Danusantoso $\mathrm{H}$, et al. Dynamic changes in pro-and anti-inflammatory cytokine profiles and gamma interferon receptor signaling integrity correlate with tuberculosis disease activity and response to curative treatment. Infect Immun 2007;75(2):820-9.

15. Gideon HP, Phuah J, Myers AJ, Bryson BD, Rodgers MA, Coleman MT, et al. Variability in tuberculosis granuloma $\mathrm{T}$ cell responses exists, but a balance of pro- and anti-inflammatory cytokines is associated with sterilization. PLoS One 2015;11(1):e1004603

16. Silva MM, Breiman A, Allain S, Deknuydt F, Altare F. The tuberculous granuloma: An unsuccessful host defense mechanism providing a safety shelter for the bacteria? Clin Dev Immunol 2012;2012:139127.

17. Suksamrarn S, Suwannapoch N, Phakhodee W, Thanuhiranlert J, Ratananukul P, Chimnoi N, et al. Antimycobacterial activity of prenylated xanthones from the fruits of Garcinia mangostana. Chem Pharm Bull 2003;51(7):857-9.

18. Gutierrez-Orozco F, Failla ML. Biological activities and bioavailability of mangostin xanthones: A critical review of the current evidence. Nutrients 2013;5(8):3163-83.

19. Tang YP, Li PG, Kondo M, Ji HP, Kou Y, Ou B. Effect of a mangostin dietary supplement on human immune function: A randomized, doubleblind, placebo-controlled trial. J Med Food 2009;12(4):755-63.

20. Sudta P, Jiarawapi P, Suksamrarn A, Hongmanee P, Suksamrarn S. Poten activity against multidrug-resistant Mycobacterium tuberculosis of $\alpha$-mangostin analogs. Chem Pharm Bull (Tokyo) 2013;61(2):194-203.

21. Koh J, Lin S, Aung TT, Lim F, Zou H, Bai Y, et al. Amino acid modified xanthone derivatives: Novel, highly promising membraneactive antimicrobials for multidrug-resistant gram-positive bacterial infections. J Med Chem 2015;58(2):739-52

22. Chen LG, Yang LL, Wang CC. Anti-inflammatory activity of mangosteens from Garcinia mangostana. Food Chem Toxico 2008;46(2):688-93.

23. Koh J, Qiu S, Zou H, Lakshminarayanan R, Li J, Zhou X, et al. Rapid bactericidal action of alpha-mangostin against MRSA as an outcome of membrane targeting. Biochim Biophys Acta 2013;1828(2):834-44.

24. Sato A, Fujiwara H, Oku H, Ishiguro K, Ohizumi Y. Alpha-Mangostin induces $\mathrm{Ca} 2+-\mathrm{ATPase}$-dependent apoptosis via mitochondrial pathway in PC12 Cells. J Pharmacol Sci 2004;95(1):33-40.

25. Song J, Yang H, Lee J, Kwon S, Jung KJ, Heo JD, et al. Standardization of bronchoalveolar lavage method based on suction frequency number and lavage fraction number using rats. Toxicol Res 2010;26(3):203-8.

26. Wolf AJ, Linas B, Trevejo-Nuñez GJ, Kincaid E, Tamura T, Takatsu K, et al. Mycobacterium tuberculosis infects dendritic cells with high frequency and impairs their function in vivo. J Immunol 2007;179(4):2509-19.

27. Cavalcanti YV, Brelaz MC, Neves JK, Ferraz JC, Pereira VR. Role of TNF-alpha, IFN-gamma, and IL-10 in the development of pulmonary tuberculosis. Pulm Med 2012;2012:745483.

28. Marakalala M, Raju R, Sharma K, Zhang YJ, Eugenin EA, Prideaux B, et al. Inflammatory signaling in human tuberculosis granulomas is spatially organized. Nat Med 2016;22(5):531-8.

29. Bai XJ, Liang Y, Yang YR, Li N, Zhang XY, An HR, et al. Immune responses to latent tuberculosis antigen Rv2659c in Chinese populations. J Microbiol Immunol Infect 2015;48(4):381-9.

30. Abebe M, Kim L, Rook G, Aseffa A, Wassie L, Zewdie M, et al. Modulation of cell death by M. tuberculosis as a strategy for pathogen survival. Clin Dev Immunol 2011;2011:678570.

31. Sreerag RS, Dileep C, Sasidharan NK. Antimycobacterail activity of crude extracts produces by Bacillus sp. associated with entomophatogenic nematode. Asian J Pharm Clin Res 2014;6(9):6-8.

32. Shi R, Sugawara I. Pathophysiology of tuberculosis. Tuberculosis: Current Issues in Diagnosis and Management. Croatia: InTech; 2013 p. 127-38. 